\title{
Enacting motherhood: time and social change in Chile
}

\begin{abstract}
Motherhood is changing. An increasing number of women are deciding to remain childless, having fewer children, postponing their transition to motherhood, and simultaneously pursuing careers. These changes are deeply embedded in a reconfiguration of the times of motherhood. Although the intersection of motherhood and time has been widely acknowledged by gender and feminist studies, less attention has been paid to how in the making of motherhood women reproduce, negotiate and subvert time mandates and norms. This article aims to underscore the importance of time and how it relates to the enactment of motherhood in contemporary societies by analysing the planning, timing, sequencing, and simultaneity of the transition to motherhood in Chile. Through the analysis of 15 life story interviews with urban women from Santiago de Chile, this article addresses the intersection between social change, motherhood and time by showing how in the making of the transitions to motherhood women reproduce, negotiate and subvert traditional and emergent cultural mandates and social norms on the times of motherhood.
\end{abstract}

Keywords: motherhood, time, social change, Chile.

\section{Enacting motherhood}

For decades, motherhood has been at the core of gender and feminist studies. Since the ground breaking Of Woman Born. Motherhood as Experience and Institution by Adrienne Rich in the mid 1970s, a significant amount of scholarly work has been devoted to account for the cultural, social, relational and subjective complexities and contradictions embedded in the experience of motherhood (Brown, Lumley, Small, \& Astbury, 1994; Davies \& Welch, 1986; DiQuinzio, 1999; Hays, 1996; Miller, 2005; Nanako Glenn, 1994; O’Reilly, 2004; 2010a; Phoenix \& Woollett, 1991a; 1991b; Rothman, 2000). One of the most important contributions of this body of work has been to understand motherhood as a social construction that is profoundly embedded in power relations. Against the biological essentialism that conflates womanhood and motherhood by arguing that the latter is a universal and unchanging female instinct (Miller, 2005, p. 55; Nanako Glenn, 1994, p. 3; O'Reilly, 2010a, p. 7), gender and feminist studies have demonstrated that motherhood is not natural, stable, fixed or constant, but rather dynamic, multiple, complex and profoundly rooted in historical, cultural, social, economic and political contexts (Hays, 1996, p. 19; O'Reilly, 2010b, p. 1106; Phoenix and Woollett, 1991b, pp. 13-14). In doing so, they have also stressed that motherhood is an oppressive institution and ideology that subordinates women. Throughout history, hegemonic social norms about motherhood have reproduced the patriarchal order by determining that women must have children and become mothers. These norms state that this is women's primary identity, role and responsibility in life and the supreme route to their physical and emotional fulfilment (O'Reilly, 2010b, p. 969; Rich, 1995, p. 22). This dominant ideology has been perpetuated through a gender division of labour where women are expected to stay at home taking care of the children and avoid seeking paid work outside the household (Lewis, 1991, p. 195; Phoenix and Woollett, 1991a, p. 8).

But how do women enact motherhood? Gender and feminist studies have demonstrated that in making motherhood as a social role, subjective experience and everyday life practice, women not only reproduce but also negotiate and subvert traditional and emergent social norms and dominant ideologies on motherhood. This means that women do not just passively reproduce motherhood but can also become active agents 
in the process of transforming and subverting it. Owing to its experiential nature motherhood becomes an ideological institution in the making (Nanako Glenn, 1994, p. 3; O'Reilly, 2010a, p. 2; 2010b, p. 572). In past decades, several empirical studies have shown how women negotiate cultural mandates and social norms in making their experience of motherhood. Bhatti and Jeffrey (2012) explore how young women in Pakistan exercise autonomy with regard to the timing of their births, the number of children they give birth to, and the decisions around fertility regulation within cultural and social constraints enforced by their parents, husbands and in-laws. Smyth (2012) analyses how women in Northern Ireland and the United States attempt to cope with the demands imposed by the role of motherhood by adopting, discarding and reconfiguring normative commitments in strategic ways with different degrees of success. And Obermeyer (2000) examines how women in Morocco negotiate notions of risk and use of health facilities during pregnancy and birth by making decisions against the backdrop of multiple constraints and alternatives for risk control.

As examples from a growing body of research, these studies exemplify the renovated approach from gender and feminist studies to the relationship between gender and agency. The work of McNay (2000), Tietjens (2002), Mahmood (2005), and Madhock (2013) among others represents an attempt to overcome simplistic and reductionist views of women's decisions, choices, actions and practices as determined exclusively by hegemonic power or individual autonomy. They do so by accounting for agency as a situational, relational, dynamic and variable capacity that emerges within the continuum of freedoms and constraints of power relations and the structures of social inequalities. This article draws on this approach to account for the way in which women reproduce, negotiate and subvert traditional and emergent cultural mandates and social norms in the making of their transitions to motherhood.

\section{The times of motherhood}

In gender and feminist studies, time has been highlighted as a relevant dimension in the making of the transition to motherhood. The intersection between motherhood and time has been mainly addressed through the temporal reconfiguration of identity in the transition to motherhood, the times of pregnancy, childbirth and nurturing, and the times of paid work, family care and leisure for mothers. Firstly, motherhood has been assessed as a significant transition that reconfigures the temporality of women's identities and biographies. Within this perspective, studies have explored how motherhood involves a narrative reorganisation of the past, present and future (Miller, 2005), the reconfiguration of self-identity (Bailey, 1999, p. 339; Sevón, 2005, p. 478), and a life-changing biographical transition (Brown, 2010, p. 126; Leccardi \& Rampazi, 1993, p. 365; Miller, 2005, p. 6; Rich 1995, p. 167). These studies show that motherhood produces a before and after in women's lives and sense of self that is highly heterogeneous both in its consequences and meanings. The extent to which motherhood represents radical or imperceptible continuities and changes in women's lives and identities, and the extent to which these are perceived as opportunities or constraints, tend to vary significantly among women. Despite these heterogeneities, in most cases motherhood is experienced through ambivalences, tensions and difficulties that challenge essentialist assumptions of motherhood as a natural female instinct.

Secondly, motherhood has been studied as a practice structured according to time. Within this perspective, studies have explored the anticipation of motherhood (Miller, 2005, p. 66), antenatal and post natal care (Miller, 2005, p. 58), the tension between 
body time and clock time during childbirth (Adam, 1995, p. 48), the timing of childbirth (Bartlett, 2010, p. 123; Miller, 2005, p. 95; O'Reilly, 2010b, p. 17; Sevón, 2005), the age of transition to motherhood (Bailey, 1999, p. 345; Berryman, 1991, p. 106; Kawash, 2011, p. 970; Phoenix \& Woollett, 1991a, p. 7; Sevón, 2005, p. 479), the notion of a 'biological clock' (Hockey \& James, 2003, p. 58; Mills, 2000, p. 9), and the maternal times of birth and breastfeeding (Bartlett, 2010). These studies reveal that women produce the timing, duration and sequence of different stages of motherhood through a negotiation of personal and relational needs, expectations and ideals. These elements are produced against the backdrop of contradictory discourses and plural normative constraints on what it means to be a 'good mother'.

Finally, motherhood has also been analysed in the context of gender differences in the time reserved for paid work, unpaid work and leisure. These studies have explored the time dedicated to motherhood (Chodorow, 1978, p. 3; Hays, 1996; Sevón, 2005, p. 462), the temporal regime of childcare (Davies \& Welch, 1986; Simons, 1984), the gendered time of care (Craig \& Mullan, 2011; Maher, 2009, p. 232), the time pressure of working mothers (Bryson, 2007, p. 134; Everingham, 2002; Rose, Hewitt, \& Baxter, 2011), and gender differences in time reserved for productive work, reproductive work and leisure (Bittman \& Wajcman, 2000; Lawler, 2000, p. 130; Maher, 2009; Mattingly \& Bianchi, 2003; Sayer, 2005; Offer \& Schneider, 2011). These studies demonstrate that motherhood is experienced against the backdrop of oppressive and demanding ideologies of time that either reduce women's lives to housework and childcare or pressurise women into performing equally efficiently both at home and in the workplace. In most cases, women's temporal experiences have negative subjective consequences such as malaise, conflict, tension, guilt, isolation, and anxiety.

Although the intersection of motherhood and time has been widely acknowledged by gender and feminist studies, less attention has been paid to the empirical process of how in the making of motherhood women reproduce, negotiate and subvert cultural mandates and social norms on the times of motherhood. This article aims to underscore the importance of time in contemporary societies' enacting of motherhood by empirically addressing the intersection between social change, motherhood and time in Chile.

\section{Motherhood and social change in Chile}

Why study the making of the times of motherhood in Chile? On the one hand, because some of the main patters of cultural and social change in Chile, such as the demographic transition and the reconfiguration of gender relations, are embedded in global trends of change. In this regard, the case is interesting because its empirical findings can be useful to make sense of how women are negotiating temporal norms and mandates in the making of motherhood in other cultural and social contexts where similar processes of change are underway. On the other hand, the contradictions and ambivalences of the processes of social change in Chile make this an interesting case for analysing the tensions, conflicts and heterogeneities that emerge in making the times of motherhood. For decades, Chile has been perceived as a role model for developing countries due to its 'success' and 'substantive progress' in democracy, governance, economic growth, individual rights and poverty reduction (Ffrench-Davies, 2014; Schmidt-Hebbel, 2009). However, Chile remains a highly conservative and unequal country. Chile has one of the lowest rates of female participation in the labour market in Latin America (Larrañaga, 2007, p. 4), divorce was only legalised in 2004, and the legalisation of 
abortion is currently under discussion in Parliament and remains highly controversial. Also, Chile is one of the most unequal countries in the world (Castillo et al., 2013; Organisation for Economic Co-operation and Development [OECD], 2013). This means that the social and subjective experience of women tends to vary significantly according to their position in the society.

Historically, motherhood in Chile has been at the core of the social roles performed by women and the definition of their self-identity. The prevalent cultural discourse based on a sexual division of labour has placed women as the foundation of reproduction and childcare (Ansoleaga \& Godoy, 2011, pp. 224-226; Valdés, 2007, p. 2). In this context, motherhood has been the core of the female self and the primary source of happiness and self-fulfilment for women (Araujo, 2005, p. 90; Montecino, 1990, p. 289; Programa de Naciones Unidas para el Desarrollo [PNUD], 2010, p. 56). Although motherhood remains essential to the lives and identities of Chilean women, it has also experienced profound transformations in the past decades. Framed in an advanced stage of demographic transition, Chile has experienced a severe decrease in fertility rates in the past decades (Cerda, 2010, p. 19; Schkolnik, 2004, pp. 34-35; The World Bank, 2011a, p. 57). At the begging of the 1960s women had on average over 5 children throughout their fertile periods. In 1961, this figure reached 5.43 children on average per woman. Since then, fertility rates have decreased to 2.72 children per women in 1979, 2.08 in 1998, and 1.80 in 2012 (Ministerio de Salud [MINSAL], Servicio de Registro Civil e Identificación, \& Instituto Nacional de Estadísticas [INE], 2014, p. 45). Additionally, data from MINSAL et al. (2014, p. 52) shows that the number of births per 1000 inhabitants in Chile has decreased from 27.2 births in 1974 to 14.0 births in 2012. This advanced stage of demographic transition in Chile is characterised by an increasing number of women that are deciding not to have children (Arriagada, 2004, p. 460). As well as having fewer children than in the past, women in Chile are also becoming mothers at an older age. While in 1979 Chile had an early fertility structure with a peak of fertility in women aged between 20 and 24 years old, today it has a late fertility structure with a peak of fertility in women aged between 30 and 34 years old (MINSAL et al., 2014, p. 27). Chilean women's postponing of motherhood is also illustrated in the delay of the birth of the first child (Arriagada, 2004, p. 460).

This reconfiguration of motherhood in Chile is linked to the transformations of gendered social roles. These transformations include an increased female participation in education and labour, the pluralisation of couple relationships, and the extension of reproductive health and alternatives (Ansoleaga \& Godoy, 2011, p. 229; Herrera, 2011, p. 29; Servicio Nacional de la Mujer [SERNAM], 2012, p. 8; Valdés, 2007, p. 2). As Pieper Mooney (2009, p. 200) argues, in Chile 'women have reconfigured the meanings of motherhood and given it multiple dimensions that reach far beyond traditional essentialized characterizations of the mother'. This reconfiguration of motherhood has been one of the most important transformations in Chile in the past decades (PNUD, 2010 , p. 125), posing several challenges to the organization of society and individual biographies. On the one hand, the reconfiguration of motherhood has been decisive in the ageing (Cerda, 2010, p. 23) and slow growth (Schkolnik, 2004, pp. 34-35) of the population, thus challenging the structure of the education and labour market, and the distribution of public resources. On the other hand, although it has been argued that in contemporary Chile women have more autonomy regarding social roles and biographical projects (INE, 2007, p. 2; SERNAM, 2012, p. 8), most institutions still demand that women perform traditional social roles related to reproduction and care 
(Godoy, 2011, p. 375; Pemjean, Toro, \& Barros, 2011, p. 157). This turns motherhood into a problematic experience that puts pressure on women when making important decisions, such as whether to have children, and when and how to become mothers (INE, 2007, p. 1).

The reconfiguration of motherhood and its social and subjective consequences has placed this phenomenon at the forefront of the public challenges of Chilean society. In the past decades, several empirical studies and theoretical reflections have aimed to account for continuities, changes and contradictions of motherhood in Chile. To do this they have addressed the factors determining fertility (Bay, Del Popolo, \& Ferrando, 2004), the legal protection of motherhood (Casas \& Valenzuela, 2011), women's rights (Pieper Mooney, 2009), maternal health policies (Alvarado \& Herrera, 2011), the tensions between motherhood, work, and health (Ansoleaga, 2011; Ansoleaga \& Godoy, 2011; Godoy, 2011; Pemjean et al., 2011), the reconfiguration of gender relations (PNUD, 2010) and family structures (Arriagada, 2004; Salvo \& Gonzálvez, 2015; Valdés, 2007), adoption and assisted reproduction (Herrera, 2011), childbirth (Murray, 2012), and the cultural mandates of women's self-identity (Montecino, 1990). The few studies that address time have described the quantitative variations of the frequency of childbearing and the timing of the transition to motherhood over time (Donoso, 2007; Fuentes, Jesam, Devoto, Angarita, Galleguillos, Torres, \& Mackenna, 2010; INE, 2006; 2007; 2008; 2014; MINSAL et al., 2014; Schkolnik, 2004; SERNAM $\&$ INE, 2004). Some of these studies have also explored women's reasons and justifications behind the temporal transformations in reproductive behaviour (Cerda, 2010; Montilva, 2008; SERNAM, 2012). However, the available studies that address the intersection of motherhood and social change in Chile too often disregard time as an essential dimension in understanding the way in which women negotiate their transition to motherhood.

\section{Data and methods}

This article addresses the times of motherhood in Chile by empirically analysing how women enact their transition to motherhood by reproducing, negotiating, and subverting traditional and emergent cultural mandates and social norms governing the planning, timing, sequencing, and simultaneity of motherhood. This article analyses 15 life story interviews conducted as part of the Proyecto Fondecyt $\mathrm{N}^{\circ} 1110402$ (2011-2013). This project aimed to reconstruct the temporal structures defining the biographical identities and life projects of individuals in the context of individualization and modernization in Chile. The life story interviews (Atkinson, 2002; Bertaux \& Kohli, 1984) were in-depth and semi-structured. They asked women about their identities, the most important events in the course of their lives, and their views about their past, present and future. Access was obtained through key informants previously known to the researchers. The interviews were conducted face to face in Spanish between May 2012 and June 2013 in the location chosen by the interviewed women. Most frequently the women chose to be interviewed in their homes, but some interviews were conducted in workplaces or public places. All of the interviews were recorded using digital audio recorders, and have an average duration of 76 minutes.

This article analyses the life story interviews of 15 urban women from Santiago de Chile $^{1}$. These women are all heterosexual women from low $(n=5)$, middle $(n=6)$, and

\footnotetext{
${ }^{1}$ Santiago is the capital city of Chile and Región Metroplitana. Data shows that the reconfiguration of motherhood in Chile has been more profound for women living in urban areas of Región Metropolitana
} 
upper $(n=4)$ class backgrounds, are aged between 18-30 $(n=5), 31-65(n=8)$, and 66-85 $(n=2)$, are engaged in different forms of coupledom $(n=7)$ or single $(n=8)$, have either from 2-5 children $(n=10)$ or no children $(n=5)$. These women voluntarily agreed to be interviewed and signed informed consent forms approved by the National Commission for Scientific and Technological Research (CONICYT) in Chile. The interviews were transcribed using a verbatim method ${ }^{2}$ and a standardised format, and had an average length of 26 single spaced pages and 11,440 words. The process of data analysis was structured according to a qualitative content analysis (Schreier, 2014, p.170) that aimed to describe systematically the features and meanings of the times of motherhood in the biographical narratives of the interviewed women. The analysis was carried out in Spanish through open, axial and selective coding (Bryman, 2012, p. 569; Flick, 2009, p. 307) using NVivo 10.

The analytical process had four main stages. Firstly, the transcribed interviews were scanned for a general impression of the available material. The passages that addressed the times of motherhood were coded with categories that synthetized their content. Secondly, the coded passages and the preliminary categories were read, grouped and organised more generally, taking into consideration both the material from the biographical narratives and the reviewed literature on the topic. Three families of codes emerged from this exercise: 1. Timing (age, biological clock, calendars, life stage), 2. Sequence (before, after, education, work, coupledom, finances, simultaneity), and 3. Temporality (past, present, future, allocation, planning, and contingency). Thirdly, the transcribed interviews were re-read and re-coded, and reports with the coded material were generated for each one of the codes. Finally, the material in each of the reports was assessed for its similarities and differences, and the identified differences were then compared with the women's self-identities, life cycle stages, and positions in the social structure.

\section{Making the times of motherhood}

Enacting motherhood is a matter of time. In the transition of becoming mothers, women shape and negotiate the time for experiencing motherhood according to their identities and roles, and to cultural mandates and social norms. In the biographical narratives of urban women from Santiago de Chile, making the times of motherhood has to do with variable levels of planning and control over the transition to motherhood, reproducing and subverting social expectations regarding the ideal timing and sequence of motherhood, and managing the simultaneity of motherhood and other social roles.

\section{Planning motherhood: contingency and uncertainty}

In contemporary urban Santiago de Chile, making the right time for motherhood is dependent on the ability to control the transition to motherhood by minimising contingency and planning the present and the future. This feature seems to be

(SERNAM \& INE, 2004, p. 73). This region has one of the lowest fertility rates and highest postponements rates in the country (SERNAM \& INE, 2004, p. 123). In 2010 women from Región Metropolitana had an average of 1.77 children, located below the national average (MINSAL et al., 2014, p. 27), and data from INE $(2007$, p. 2) shows that in 2004 this region had the highest percentage of mothers aged between 30 and 39 years old.

${ }^{2}$ In translating the verbatim quotes of the interviews from Spanish to English for this article, the language was standardised and the pauses and non-verbal utterances eliminated to provide coherence to text. In doing this, I aimed to maintain the literalness of the expressions and respect the meaning intended by the interviewees. 
characteristic of modern Western societies where life plans have become fundamental to the purposeful and reflexive organisation of individual lives (Giddens, 1991, p. 85; Kohli, 2007, p. 77; Leccardi, 2005, p. 124). As Beck and Beck-Gernsheim (2002, p. 126) argue, in this context having children has become increasingly the object of conscious planning and calculation. Nevertheless, the transition to motherhood not always occurs as a rationally and reflexively planned event. In the life stories of urban women from Santiago de Chile, pregnancy is frequently narrated as unexpected. Words like 'unplanned', 'accident' and 'surprise' account for an enacting of motherhood as a contingent event that occurs independently from rational calculation and purposefulness. Andrea, a 28 year old middle class woman with two children, narrates how she became a mother for the first time; 'My husband and I were a couple from the age of 15 to 18 . When we were 18 we broke up, and afterwards I realised that I was 4 months pregnant'. Marisol, a 54 year old lower class woman with three children, recalls the first time she got pregnant; 'When I met my husband we went out for three months, and I had such bad luck because I got pregnant'. What is common to the narratives of motherhood of Andrea, Marisol and some other interviewed women is that since pregnancy occurs as an unexpected event, motherhood is experienced as disruptive and unintended transition that produces biographical uncertainty. In this context, unexpected motherhood forces them to rearrange their identities, everyday life practices, relationship commitments, and future aspirations.

By reflexively interpreting their past, urban women from Santiago de Chile make sense of their unexpected pregnancies with an awareness of their irresponsibility or a lack of information. While some of them comprehend their unplanned pregnancies as the result of irresponsible behaviour, others acknowledge their ignorance regarding contraception and reproductive health due to lack of information on planning reproduction. When explaining the reasons behind her first pregnancy, Andrea mentions; 'getting pregnant involves decisions: in my case I was maybe not taking enough care of myself by not using contraception'. Similarly, for Susana, a 42 year old lower class woman with four children, her first pregnancy was unintentional. She explains this happened because she lacked the knowledge and experience required for 'successful' use of contraception: 'I didn't have a lot of experience in taking care of myself. I was a little bit ignorant'. The narrated experiences of unexpected pregnancies suggests that agency in the reflexive planning of motherhood is profoundly embedded in social inequalities. Indeed, access to contraception and information about how to use it properly, knowledge about reproductive health, sexual autonomy, and the repertoires of justification for individual choice tend to vary significantly between social classes in urban Santiago de Chile. This is highly consistent with the results of a study conducted by Dusaillant (2009, cited in PNUD, 2010, p. 189) that demonstrates that unintended pregnancies correlate to social class in contemporary Chile.

Narratives of unexpected motherhood tend to be articulated through strong linkages between being pregnant and becoming a mother. Once urban women from Santiago de Chile found out they were pregnant the transition to motherhood was usually passively assumed as a natural path of continuity. However this implicitly extended identity between pregnancy and motherhood was tensioned and fragmented when women were confronted with alternatives. When Andrea found out that she was pregnant, the doctor confronted her with the decision to terminate her pregnancy. As she narrates; 'I started to realise that the woman was recommending an abortion, and I said "no, stop it, I'm not going to abort my child"'. The story of Andrea portrays how by being confronted with 
alternatives, the identity between unexpected pregnancy and unintended motherhood become a possibility among others and a matter of choice, enabling agency both in the decision of continuing or terminating pregnancy. As it has been argued by Rich (1995, p. 76) and Sevón (2005, p. 461), the availability of alternatives to pregnancy has transformed motherhood from a destiny to an individually chosen way of life. However, greater individual autonomy in deciding whether or not to stay pregnant remains a highly complex issue in contemporary Chile. The prevalent influence of the Catholic doctrine continues to constrain women's reproductive choices and is reflected in the fact that Chile has one of the most restrictive abortion legislations in the world (Herrera, 2011, p. 29).

Agency in enacting motherhood emerges not only in the de-naturalisation of the identity between pregnancy and motherhood, but also in the possibilities of change over time. The biographical narratives of urban women from Santiago de Chile illustrate how after an unexpected pregnancy women reflexively undertake actions related to contraception and reproductive health to gain control over their sexuality and reproductive process. After having two daughters through unexpected pregnancies, Carmen, a 52 year old lower class woman, and her husband decided not to have any more children; "we wanted to have our two daughters but then I had surgery so as not to have any more children'. Similarly, after having a son and a daughter through unintended pregnancies, Gladys, a 52 year old lower class woman, decided that she didn't want to have any more children. As she narrates 'then I started a treatment and I said to myself "I'm not having any more children"'. The stories of Carmen and Gladys show that agency in enacting motherhood is expressed not only through the possibility of constructing the future by reflexively avoiding reproducing the past, but also by gaining control and autonomy over sexuality and reproduction.

But motherhood does not always come about unexpectedly. The stories of the transition to motherhood also indicate it is an expected event or future project for women who have yet to become mothers. However, while most of the women that have not yet had children envisage motherhood as part of their futures, this aspiration is not structured as a plan with concrete times. In discussing her desires to form a family, Catalina, a 28 year old upper class woman with no children, suggests she has an abstract and undefined vision of the times of her future motherhood; 'it is something abstract, I don't have a date, I don't have anything planned, but it is something that I'm looking for'. Similarly, Isabel, a 32 year old middle class woman with no children, illustrates the difficulties associated with planning her future transition to motherhood; 'if you already have everything planned for many years ahead, you will probably end up being frustrated, because you have so many expectations that usually don't turn out as you planned'. A highly contingent and uncertain account of the future is revealed when the interviewed women narrate the difficulties of planning the transition to motherhood. This is consistent with the biographical consequences of uncertainty outlined by Beck and Beck-Gernsheim (2002, p. 3). For Leccardi (2005, p. 124), this means that future plans and aspirations 'are shaped by the understanding of the unpredictability of the future and the constant flexibility that this requires'. The constraints in planning the future outlined in these narratives reveal the extent to which individual agency in the making of the timing of motherhood is inherently linked to a broader understating of the structure of temporality and its particular meaning.

Timing motherhood: negotiating biological times 
Gender and feminist studies have widely acknowledged how the timing of the transition to motherhood is negotiated against the backdrop of normative temporal limits that define when it is possible and expected for women to become mothers (Bailey, 1999, p. 345; Berryman, 1991, p. 106; Phoenix \& Woollett, 1991a, p. 7; Sevón, 2005, p. 479). Age plays a fundamental role in the definition of the temporal limits of motherhood by setting norms, expectations, constraints and sanctions to the chronological time of childbearing (Clausen, 1986, pp. 3-4; Elder, 1994, p. 6; Settersten, 2003, p. 81). In the biographical narratives of urban women from Santiago de Chile, chronological age emerges as the normative foundation that defines the right and wrong time to experience the transition to motherhood.

In the biographical narratives of urban women from Santiago de Chile, women are considered 'too young' to become mothers when their transition to motherhood occurs when they are 18 years old or under. According to prevalent social norms reproduced by women, by becoming mothers at that age they are skipping relevant life stages and lack the maturity and preparation to take care of children appropriately. This social norm is clearly illustrated in Marisol's discourse on teenage pregnancy;

I think that it is not very good, imagine there are little girls that are 14 o 15 years old and have children, where do those children live? Then there are problems because that girl doesn't act responsibly. They screw up their lives. I say that they screw up their lives because they don't live what they should be living, because everything has its time in life: at a certain age you do this, at another age you do that. There is always a stage in life to do certain things.

This social norm regarding adolescent motherhood is also illustrated in the autobiographical memories of Gladys. Discussing the time when she became a mother, she states;

I don't regret having my children, but it think I had them at the wrong age. I was too young, I skipped stages, several stages of my life, and I missed things that I ended up experiencing afterwards when I was older, hurting my children.

The prevalent social norms reproduced by urban women from Santiago de Chile also state that women are 'too old' to become mothers when their transition to motherhood occurs when they are 35 years or older. In contemporary Chile, this social norm is predominantly reproduced and validated by medical discourses. Among many others, Fuentes et al. (2010, p. 1241) argue that as women's age increases, so does the risk of infertility, chromosome foetal anomalies, spontaneous abortions, the frequency and severity of pregnancy pathologies, and the probability of still, premature and low weight births. This discourse is part of what Dubriwnt and Ramadurai (2013) refer to as the neoliberal risk frame of medical establishment where women 'are empowered to make a birthing choice based on individualized risk assessment and ultimately are responsible for all ramifications of that choice' (p. 254). Among others, this discourse tends to portray women's sexual and reproductive agency as unhealthy and dangerous both subjectively and socially (McAlister 2015).

When discussing the right time to become a mother, Antonia, a 24 year old upper class woman with no children, mentions; 'you cannot have children after 40 because afterwards they are born with problems'. This same social norm emerges in the narrative of Carmen when she discussed wanting to become a mother for the first time when she was over thirty years old; 'it is said that women have problems having children when they are older, so I used to tell myself that I was on the edge'. Together 
with the dominant discourse of the biological limits of motherhood, emerges an alternative discourse of the social limits of motherhood. When discussing her possibility of becoming a mother for the first time, Laura, a 45 year old middle class woman with no children, argues;

It is biological but it is also social, in the sense that..., I do believe that at this age having a child is more difficult biologically, but also, if the child comes, I think that it is more difficult... practically. It is not the same having a child at 20 as it is at $45(\ldots)$. I could decide to have a child and say ok, but a kid of 15 years old having a mum of $60 \ldots$ is that fair for the child?

The temporal limits of motherhood in contemporary urban Santiago de Chile are strongly embedded in the notion of a 'biological clock'. This notion usually refers to the biological determination of the temporal finitude that constrains the female reproductive process (Hockey \& James, 2003, p. 58; Mills, 2000, p. 9). When discussing the right time to become a mother, Antonia refers to the existence of a 'cruel biological clock' in women. For her;

As a woman, you have a limited fertile period in your life. Not like men, who don't have a limited fertile period because they are fertile their whole lives. By contrast, women can't have children after 40 (...). You have a biological clock inside you, you know that you can be a mother until a certain age and no further.

The biographical narratives of the interviewed women show that the transition to motherhood in contemporary urban Santiago de Chile is enacted through an increasing reflexive awareness of the temporal limits of motherhood. These limits remain profoundly embedded and constrained by a biological essentialism that restricts the temporal possibilities of the transition to motherhood to the socially constructed biological limits of the female reproductive process. As it has been stressed by studies on 'early' (Briggs, Brownell, \& Roos, 2007; Lee, 2010) and 'late' (Beets, Schippers, \& te Velde, 2011; Bulanda \& Lippmann, 2012) motherhood, the timing of the transition to motherhood is profoundly embedded in social inequalities. In contemporary urban Santiago de Chile this is expressed in the fact that women who experience the transition to motherhood at a young age tend to have vulnerable life trajectories characterised by a precarious background and unfavourable educational, labour, and economic outcomes. Conversely, women who experience the transition to motherhood at an older age tend to come from more privileged backgrounds, have higher levels of educational achievements and occupy better positions in the labour market.

Nevertheless, not all narratives on motherhood are structured around strict biological limits. Together with this dominant social norm, emerges an alternative narrative that flexibilises the temporal limits of motherhood by uprooting them from the biological constraints of the reproductive process. When discussing the right age to have children, Isabel argues; 'I don't believe that there are limits for that, it depends on the meaning that you give to it (...) I don't know, it could be 40, 45, they could be adopted... there are no limits'. This perception of adoption as a strategy that subverts the biological limits of motherhood is also acknowledged by Antonia; 'being a mother is going to be an issue when the time to have children comes, and if then I can't have children, I'll adopt'. This understanding of timing of motherhood desembedded from a biological determinism tends to be more common in younger middle and upper class women, and represents an increasing sense of agency and reflexivity in defining the temporality of the transition to motherhood. Nevertheless this emerging perception should be interpreted cautiously because as Herrera (2011, p. 41) and Salvo and Gonzálvez (2015, 
p. 43) have argued, in contemporary Chile non-biological alternatives to motherhood tend to be hierarchized as a second choice after biological reproduction.

In the biographical narratives, the biological foundations of motherhood were also challenged by affective struggles during pregnancy and by the emergence of motherhood as a social role beyond childbearing. In narrating motherhood, urban women from Santiago de Chile manifest a strong identity between having children and developing a sense of self as mothers. As Miller argues (2005, p. 54) 'the biological fact of giving birth within Western cultures simultaneously leads to a redefinition of an individual's identity, an identity which is inextricably linked to family and motherhood'. Nevertheless, some experiences of childbearing account for a desynchronization and fragmentation of the biological, subjective and social dimensions of motherhood. When Gladys found out that she was pregnant with her third child, she struggled to feel affection for the child and become his mother. As she narrates; 'I never wanted him, if it were for me I wouldn't have had him. I didn't prepare or buy anything because for me he didn't exist'. Experiences such as Gladys's subvert the naturalised identity between having a child and becoming a mother by illustrating that motherhood as an identity and sense of self is not universally bound to the biological act of giving birth. This is also relevant in Alicia's narrative, who recalls being like a mother to one of her housemaids; 'she lived with me more than 30 years, more than she lived with her mum. So I tell her "I raised you like I raised my girls because I taught you everything I knew"'. This extended understanding of motherhood emerges when the categories of mother and child become purely symbolic as they are stripped from biological determination. As argued by Montecino (1990, p. 289), this extended motherhood in Chile means that the female self as mother is not restricted to biological motherhood, but extended as a social role in different life domains.

\section{Sequencing motherhood: making the before}

Making the times of motherhood also involves locating it in a sequence defined by an ordered succession of events according to the logic of before and after. The biographical narratives of urban women from Santiago de Chile account for increasing constraints in the sequencing of motherhood, by placing coupledom and a good financial situation as conditions that must be fulfilled before the transition to motherhood can be undertaken.

In contemporary urban Santiago de Chile, motherhood seems to be deeply embedded in coupledom. The social expectation of women to be married or in a relationship before becoming mothers has been widely acknowledged in gender and feminist studies (O'Reilly, 2010b, p. 504; Phoenix \& Woollett, 1991b, p. 15), and remains a prevalent social norm in Chile. As Herrera (2011, p. 29) argues, 'having children is considered to be the 'natural' way of things for every person and couple in Chile. It is well-accepted and expected that a man and woman get married and eventually have one or more children'.

In the biographical narratives of urban women from Santiago de Chile, being in a relationship is the context that enables the transition to motherhood, and having a stable partner is often enunciated as a condition that must be met before having a child. In discussing her desire to be a mother, Catalina asserts that before becoming a mother she must find a suitable partner; 'first I have to find the future husband, and when that happens I can have children..., because now I'm single'. When recounting the time when she realised that she was pregnant with her first child, Andrea remembers her 
concern about not having a partner; "the doctor told me "you are pregnant" during an ultrasonography, and I said "it cannot be, I don't have a boyfriend"”. Although marriage as an institution remains highly valued as a prerequisite in enacting motherhood, this criterion has been flexisibilised over time. As Liliana, an 83 years old middle class woman with four children, argues;

I think that it has changed, because now it is quite normal for kids to become a couple without marriage. In the times when we were young it was a terrible sin, just like having a child without being married, it was a terrible sin, and now is not.

The persistent relevance of coupledom in the sequencing of the transition to motherhood in Chile becomes interesting when we consider a parallel increasing trend of single motherhood by choice in Western developed countries. Donovan (1982-1983) and Potter and Knaub (1988) argue that since the 1960s, together with the proliferation of assisted reproductive technologies, an increasing number of unmarried women are intentionally deciding to have and raise their children on their own. For Bock (2000, p. 83), single motherhood by choice emerges as clearly differentiated from other forms of single motherhood like teenage pregnancy, underlining women's determination, autonomy and intension in experiencing the transition to motherhood outside marriage and coupledom. In Chile, Salvo and Gonzálvez (2015) argue that single motherhood by choice has increased despite the constraints and limitations associated with the access to assisted reproductive technologies and adoption for single women. Despite this incipient process of change, the analysed biographical narratives demonstrate that in contemporary urban Santiago de Chile the transition to motherhood remains profoundly embedded in coupledom, although to a lesser extent in marriage, and thus highly constrained by and dependant on a male partner.

In narrating their experiences of motherhood, urban women from Santiago de Chile also recognise the importance of having a good financial status prior to the transition to motherhood. This is highly consistent with the argument of Cerda (2010, p. 20) who states that currently in Chile socioeconomic factors are fundamental in the decision to have children. Having a bigger house and being able to provide for the education and nurturing of their children are usually mentioned as relevant aspects of motherhood that are enabled by a stable economic condition. When mentioning her desire to have more children, Andrea acknowledges the importance of money; 'if you earn more money you can have access to more things, and I think that several of those projects, even having children, is a matter of money, for me at least'. Having limited financial resources is also often mentioned as a limitation to having children. For Laura, not having enough money influenced her decision not to have children while she was a graduate student; 'I also had very little money,... imagine, doing a $\mathrm{PhD}$ with a scholarship that was barely enough, I wouldn't even have had money for the nappies'. The financial requirements associated with becoming a mother tend to be more significant for younger lower and middle class women and impose several constraints on enacting motherhood. For Cerda (2010, p. 20) and SERNAM (2012, p. 56), this has been determinant in the postponement of motherhood and the decrease of fertility rates in Chile.

\section{Simultaneous motherhood: performing multiplicity}

Enacting motherhood increasingly involves reconciling and coordinating multiple social roles in everyday life. Structural and institutional contradictions and conflicting social norms emerge when urban women from Santiago de Chile attempt to perform multiplicity by enacting motherhood while simultaneously engaging in paid work outside the household. 
Together with the traditional cultural conception of motherhood as embedded in private reproduction and childcare (Montecino, 1990, p. 289), an alternative social mandate that conflates motherhood with the responsibility for the material reproduction of children is emerging in contemporary Chile. For Pilar, a 52 year old middle class woman with two children, having children implies assuming the responsibility of economic and material provision. As she narrates;

The thing is that you are obliged to do it, I mean you can't avoid things that you are responsible for. I mean, when you have a child, it comes with a whole story. I mean, it's not only the, the romantic thing, I mean, you have to pay for school, you have to... and that is the real thing from the real world, do you understand?

Pilar's experience is highly consistent with an emerging ideology that expects mothers not only to take care of their children and fulfil the demands of intensive nurturing, but also financially support their children (Hays, 1996, p. 131; Lewis, 1991, p. 197; Miller, 2005, p. 55). For Thornton (2014, p. 275) this predominant ideology fuses motherhood with the capitalist discourse of individual achievement and productivity. As for Pilar, for most single mothers multiplicity was not an option given that work became indispensable as the principal manner to provide for the material reproduction of their children. This is relevant when considered in the context of the significant growth of female headed households in Chile, from 10\% of the total households in Chile in 1982 to $31.5 \%$ in 2002 , representing an $85.1 \%$ of the total of mono-parental households (INE, 2008, pp. 35-36). Because it is entrenched in social inequalities, performing multiplicity tends to be more critical for single lower class woman. As Gladys argues; 'but you have to work, because if you don't work, how do you feed them?'. Similarly, Susana explains to her children why she works;

I tell them the truth, I tell them "I don't go to work because I have enough or plenty, I have to work so that you can eat and I can buy what you need so that you can keep studying".

For most urban women from Santiago de Chile with partners, working through motherhood remains subordinated to the family project or becomes an activity performed for personal reasons. Together with her partner, Andrea decided that she was going to work less to spend more time with her children;

Now we have decided as a couple that I will work less or part-time, or always work from March to December. I have always worked like that, even though I worked in other places that weren't schools I have also worked this way, from March to December, to spend more time with the children.

For Marisol, work is something she does for herself; 'because I work for myself, to entertain myself. It is like a hobby so that I don't feel so lonely and I don't have the feeling that I am all day in the house doing nothing'.

In storying motherhood, working women reveal several tensions when simultaneously performing motherhood and work. Gladys remembers working while having young children as a terrible experience;

If you leave them with someone, you wonder "are they going to be ok? Are the [helpers] going to give him what you left for him?" And that wherever you are, at work, your head is not there, it is with your child because your maternal instinct tells you that he is not being well cared for. Sometimes you get there and your children are sick because the [helpers] don't take good care of them, and that is terrible for you. 
Similarly, for Pamela, a 25 year old lower class woman with two children, working is one of the most difficult things to do while being a mother; 'the most difficult thing is to work... Sometimes for me is difficult to work while being worried for the younger one who is at the nursery, that something might happen to her'.

These contradictions that women experience in performing motherhood and paid work are to a great extent a matter of time. Not only because performing multiplicity demands an efficient time management in everyday life, but also because it requires integrating different chronologies and cultural mandates of time. McAlister (2008) shows the complexities involved in reconciling the pressures and demands of the clocks of professional and family life, and Gilbert and von Wallmenich (2014) reveal how women struggle to experience motherhood in the context of a hegemonic cultural mandate of time as linear, and focus on schedules, times and sequences. Faced with the need to simultaneously work and take care of their children, urban women from Santiago de Chile develop different strategies to reconcile both domains in everyday life. As Araujo (2005) has argued, paid domestic service is one of the main strategies through which Chilean women reconcile motherhood and work. When discussing the future difficulties of becoming a mother and maintaining her current working schedule, Catalina mentions;

Sure, exactly, I'll manage somehow. Also, I have seen it. For example, the lawyer who was next door left work during the prenatal period, she had to leave obviously, and then she went back to work and now takes the baby to nursery.

These strategies tend to be highly constrained by class and the availability of resources to solve contradictions. When women don't have the economic resources to pay for domestic service and can't rely on family networks to support them with childcare, they perform multiplicity at the expense of their time and wellbeing. This experience is illustrated in Susana's account of how she manages to reconcile her work schedule and taking care of her children;

How I organise everything, well, it is very difficult. I wake up very early, like at six in the morning. At night I go to bed at one, two in the morning to have lunch ready for the next day.

The strategies that allow reconciling motherhood and work in everyday life always refer to individual efforts and sacrifices. As it has been stressed by Ansoleaga and Godoy (2011, p. 228) in Chile all the costs, difficulties and contradictions of integrating motherhood and work tend to be solved by women on their own. This seems to be a characteristic feature of Western individualised societies that compel individuals to 'seek biographical solutions to systemic contradictions' (Beck \& Beck-Gernsheim, 2002, p. xxii).

What seems to be highly common to the stories of Gladys, Pamela, Susana and all the interviewed women who had to work during motherhood is a subjective feeling of guilt and distress for neglecting the care of their children, and a deterioration of their wellbeing. For Gilbert (2008, p. 204), this emerges as a consequence of a strict normative account of motherhood that denies and makes invisible the power and effects of real life ambivalences. In Chile, it has been widely acknowledged that in integrating motherhood and work women experience guilt, frustration, emotional and physical wariness, and deterioration of mental health (Ansoleaga \& Godoy, 2011, pp. 222-223; Pemjean et al., 2011, p. 75). These subjective consequences of performing multiplicity are also highly embedded in social inequalities. As Araujo (2005, pp. 97-98) has argued, in Chile 
women from lower socioeconomic levels who work full time and have young children tend to present high levels of dissatisfaction and malaise. These levels are considerably higher than those of women from upper socioeconomic levels who have more possibilities and resources to develop strategies to perform multiplicity.

The biographical narratives of motherhood of urban women from Santiago de Chile account for conflicting cultural mandates in performing simultaneity. On the one hand, simultaneity is constructed as a positive ontological feature of womanhood. The capacity of dealing with different demands at the same time is perceived to be a positive feature of the female nature and to what it is to be woman. When talking about womanhood, Marisol states; 'as women, we are more resistant, we are more resistant, we can be mothers, we can work, we can do many things. Men can't'. As Montecino (1990, p. 289) has argued, in Chile the prevailing idea of motherhood defines women as beings with the ability and responsibility to perform flawlessly at home, work and in their relationships, who are capable of doing everything simultaneously. This is highly consistent with an emerging ideology of motherhood that defines women as successful in integrating different social roles (Hays, 1996, p. 131; Miller, 2005, p. 55).

On the other hand, in the biographical narratives of urban women from Santiago de Chile simultaneity is perceived a negative structural incompatibility, meaning that it is not possible to perform motherhood and work well at the same time. For Liliana, it is just too difficult to reconcile multiplicity;

Even now it is very difficult for women to work and take care of their children, both things are too difficult. Either she works and takes care of her work, or she takes care of the children and neglects work, but doing both things at the same time is too difficult.

Liliana's perspective on performing multiplicity is highly consistent with a dominant ideology of motherhood where the ideal mother is defined as one who does not work outside the home (Lewis, 1991, p. 195). This cultural mandate defines the structural incompatibility of simultaneity by stating that women cannot be good mothers and work at the same time. This is evident in the everyday struggle of single lower class women from urban Santiago de Chile. In having to leave their children to go to work Susana feels that she is not a good mother; 'sometimes I feel like a bad mother that abandons her children a lot. I feel that my children are abandoned'. She adds;

I feel that I am a little distanced from my children. Well, distanced for leaving your house. You used to be there all the time and suddenly you leave from sunrise to dawn.... But then, I have to leave that aside because I don't leave the house because I want to, but because I have to. I have to work for my children.

\section{Conclusions}

This article has empirically revealed how time is at the core of enacting motherhood in contemporary urban Santiago de Chile. In the making of their transitions to motherhood, women reproduce and reinforce traditional and emergent cultural mandates and social norms on the times of motherhood. They do so by constraining the timing of motherhood to the biological limits of the reproductive process, by sequencing motherhood after marriage and coupledom, by restricting the frequency of motherhood to economic conditions, and by morally disapproving of the simultaneity of motherhood and paid work. But in the making of their transitions to motherhood, women also negotiate and subvert traditional and emergent cultural mandates and social norms on the times of motherhood. They do this by desembedding the timing of motherhood from biological constraints, by disregarding marriage as a prerequisite for the transition to 
motherhood, and by deploying multiple strategies to reconcile motherhood and work in everyday life.

Enacting motherhood in contemporary urban Santiago de Chile is a highly heterogeneous process. In storying their lives, women reflect profound age and class differences in bringing motherhood into being. On the one hand, while older women tend to remain more compliant with cultural mandates and social expectations, younger women present a more reflexive and agentic enacting of motherhood expressed through increasing levels of choice, purposefulness and planning. This cohort difference in enacting motherhood accounts for significant cultural transformations and social changes in the way in which urban women from Santiago de Chile enact motherhood. On the other hand, while middle and especially upper class women tend to deploy a more reflexive and agentic enacting of motherhood due to their greater decision space, possibilities and resources, for lower class women enacting motherhood remains constrained and determined by cultural mandates and social norms. This class difference accounts for profound social inequalities in the way in which women enact motherhood, and reveals that the transition to motherhood is a not just an individual decision because it is profoundly constrained by social structures, institution and social relations.

By stressing the relevance of time in the enacting of motherhood in Chile, this article has provided a highly consistent insight to comprehend why women in contemporary societies are postponing motherhood, having fewer children and deciding not to have children, while progressively engaging with paid work. To further advance these finding, future studies should explore cross-cultural comparisons of the transformation of the prevalence, frequency, timing, sequencing and simultaneity of motherhood. It would also be insightful to develop a more advanced characterisation of the traditional and emergent cultural mandates and social norms on the times of motherhood, and explore how the latter are negotiated within situated social relations.

Word count: 9,273 words.

\section{References}

Adam, B. (1995). Timewatch. The Social Analysis of Time. Cambridge: Polity Press.

Alvarado, N. \& Herrera, T. (2011). Políticas públicas de salud desarrolladas en Chile durante el último siglo. In: Ansoleaga, E. Mujer, Trabajo, Maternidad, Salud. Tensiones no resueltas del siglo XX y propuestas para el Bicentenario (pp. 89119). Santiago: UDP.

Ansoleaga, E. (2011). Mujer, Trabajo, Maternidad, Salud. Tensiones no resueltas del siglo XX y propuestas para el Bicentenario. Santiago: UDP.

Ansoleaga, E. \& Godoy, L. (2011). Maternidad, trabajo y salud: la voz de los actores sociales. In: Ansoleaga, E. Mujer, Trabajo, Maternidad, Salud. Tensiones no resueltas del siglo XX y propuestas para el Bicentenario (pp. 209-297). Santiago: UDP.

Araujo, K. (2005). Vida cotidiana y transformaciones de género: la esfera doméstica. Revista de la Academia, 10, 77-117. Retrieved from http://bibliotecadigital.academia.cl/bitstream/handle/123456789/2808/77117.pdf? sequence $=1$ \&is Allowed $=\mathrm{y}$

Arriagada, I. (2004). Cambios y continuidades en las familias latinoamericanas. Efectos del descenso de la fecundidad. In: La fecundidad en América Latina: 
¿Transición o revolución? Serie Seminarios y Conferencias $N^{\circ} 36$ (pp. 453471). Santiago: CELADE-CEPAL.

Atkinson, R. (2002). The life story interview. In: Gubrium, J.F. and Holstein, J.A. eds. Handbook of Interview Research. Context and Method (pp. 121-140). Thousand Oaks, California and New Delhi: Sage Publications.

Bailey, L. (1999). Refracted Selves? A Study of Changes in Self-Identity in the Transition to Motherhood. Sociology, 33(2), 335-352. doi: 10.1177/S0038038599000206.

Bartlett, A. (2010). Babydaze: Maternal time. Time \& Society, 19 (1), 120-132. doi: 10.1177/0961463X09354419

Bay, G., Del Popolo, F., \& Ferrando, D. (2004). Determinantes próximos de la fecundidad. Una aplicación a países latinoamericanos. In: La fecundidad en América Latina: ¿Transición o revolución? Serie Seminarios y Conferencias $\mathrm{N}^{\circ}$ 36 (pp. 185-211). Santiago: CELADE-CEPAL.

Beck, U. \& Beck-Gernsheim, E. (2002). Individualization. Institutionalized Individualism and its Social and Political Consequences. London, Thousand Oaks and New Delhi: SAGE Publications.

Beets, G., Schippers, J., \& te Velde, E. R. (2011). The Future of Motherhood in Western Societies. Late Fertility and its Consequences. Dordrecht, Heidelberg, London and New York: Springer.

Berryman, J. C. (1991). Perspectives on Later Motherhood. In: Phoenix, A. et al. (Eds.) Motherhood. Meanings, Practices and Ideologies (pp. 103-122). London, Newbury Park and New Delhi: Sage Publication.

Bertaux, D. \& Kohli, M. (1984). The life story approach: a continental view. Annual Review of Sociology, 10, 215-237. doi: 10.080184.001243.

Bhatti, F. \& Jeffrey, R. (2012). Girls' schooling and transition to marriage and motherhood: exploring the pathways to young women's reproductive agency in Pakistan. Comparative Education, 48 (2), 149-166. doi: 10.1080/03050068.2011.608894.

Bittman, M. \& Wajcman, J. (2000). The Rush Hour: The Character of Leisure Time and Gender Equity. Social Forces, 79 (1), 165-189. doi: 10.1093/sf/79.1.165

Bock, J. D. (2000). Doing the Right Thing? Single Motherhood by Choice and the Struggle for Legitimacy. Gender \& Society, 14 (1), 62-86. doi: 10.1177/089124300014001005

Briggs, G., Brownell, M., \& Roos, N. (2007). Teen Mothers and Socioeconomic Status. The Chicken-Egg Debate. Journal of the Association for Research on Mothering, $\quad 9 \quad$ (1), 62-74. $\quad$ Retrieved from http://jarm.journals.yorku.ca/index.php/jarm/article/viewFile/5136/4332

Brown, S., Lumley, J., Small, R. \& Astbury, J. (1994). Missing Voices. The Experience of Motherhood. Melbourne: Oxford University Press.

Brown, I. (2010). Ambivalence of the Motherhood Experience. In: O'Reilly, A. (Ed.) Twenty-first-Century Motherhood. Experience, Identity, Policy, Agency (pp. 121-139). New York: Columbia University Press.

Bryson, V. (2007). Gender and the Politics of Time. Feminist theory and contemporary debates. Bristol: The Policy Press.

Bryman, A. (2012). Social Research Methods. 4th ed. Oxford and New York: Oxford University Press.

Bulanda, R. E. \& Lippmann, S. (2012). The Timing of Childbirth and Family-to-Work Conflict. Sociological Focus, 45, 185-202. doi: 10.1080/00380237.2012.686090 
Casas, L. \& Valenzuela, E. (2011). De la protección de la primera infancia a la protección de la familia. In: Ansoleaga, E. Mujer, Trabajo, Maternidad, Salud. Tensiones no resueltas del siglo XX y propuestas para el Bicentenario (pp. 1387). Santiago: UDP.

Castillo, J. C., Miranda, D., \& Madero Cabib, I. (2013). Todos Somos de Clase Media. Sobre el estatus social subjetivo en Chile. Latin American Research Review, 48 (1), 155-173. Retrived from https://lasa.international.pitt.edu/LARR/prot/fulltext/vol48no1/48-1_155173_castillo-cabib.pdf

Cerda, R. (2010). Familia y fecundidad. In: Encuesta Nacional Bicentenario Universidad Católica - Adimark 2009 'Una mirada al alma de Chile'. Temas de la Agenda Pública Nº 36 (pp. 19-24). Santiago: Pontificia Universidad Católica de Chile.

Clausen, J. A. (1986). The life course. A sociological perspective. New Jersey: PrenticeHall.

Craig, L. \& Mullan, K. (2011). How Mothers and Fathers Share Childcare: A CrossNational Time-Use Comparison. American Sociological Review, 76 (6), 834861. doi: 10.1177/0003122411427673

Davies, B. \& Welch, D. (1986). Motherhood and Feminism: Are They Compatible? The Ambivalence of Mothering. Journal of Sociology, 22 (3), 411-426. doi: $10.1177 / 144078338602200305$

DiQuinzio, P. (1999). The Impossibility of Motherhood. Feminism, Individualism and the Problem of Mothering. New York and London: Routledge.

Donoso, E. (2007). Descenso de la natalidad en Chile: un problema país. Revista Chilena de Ginecología y Obstetricia, 72 (2), 73-75. doi: 10.4067/S071775262007000200001

Donovan, C. A. (1982-1983). The Uniform Parentage Act and Nonmarital MotherhoodBy-Choice. Review of Law and Social Change, XI (2), 193-253. Retrieved from http://heinonline.org/HOL/Page?handle=hein.journals/nyuls11\&div=17\&g_sent $=1 \&$ collection $=$ journals

Dubriwny, T. N. and Ramaduri, V. (2013). Framing Birth: Postfeminism in the Delivery Room. Women's Studies in Communication, 36 (3), 243-266. doi: 10.1080/07491409.2013.830168

Elder Jr., G. H. (1994). Time, Human Agency and Social Change: Perspectives on the Life Course. Social Psychology Quarterly, 57 (1), 4-15. Retrieved from http://www.jstor.org/stable/2786971

Everingham, C. (2002). Engendering time. Gender equity and discourses of work place flexibility. Time \& Society, 11 (2/3), 335-351. doi: 10.1177/0961463X02011002009

Flick, U. (2009). An Introduction to Qualitative Research. 4th ed. London, Thousand Oaks, New Delhi and Singapore: SAGE Publications.

Ffrench-Davies, R. (2014). Is Chile a Model for Economic Development? Serie de Documentos de Trabajo $N^{\circ} 392$, Facultad de Economía y Negocios, Universidad de Chile.

Fuentes, A., Jesam, C., Devoto, L., Angarita, B., Galleguillos, A., Torres, A., \& Mackenna, A. (2010). Postergación de la maternidad en Chile: Una realidad oculta. Revista Médica de Chile, 138, 1240-1245. doi: 10.4067/S003498872010001100005

Giddens, A. (1991). Modernity and Self-Identity. Self and Society in the Late Modern Age. Cambridge: Polity Press. 
Gilbert, J. (2008). Why I Feel Guilty All the Time: Performing Academic Motherhood. Women's Studies in Communication, 31 (2), 203-208. doi: 10.1080/07491409.2008.10162533

Gilbert, J. and von Wallmenich, L. (2014). When Words Fail Us: Mother Time, Relational Attention, and the Rhetorics of Focus and Balance. Women's Studies in Communication, 37 (1), 66-89. doi: 10.1080/07491409.2013.867915

Godoy, L. (2011). Maternidad y trabajo: las voces de las madres trabajadoras. In: Ansoleaga, E. Mujer, Trabajo, Maternidad, Salud. Tensiones no resueltas del siglo XX y propuestas para el Bicentenario (pp. 340-389). Santiago: UDP.

Hays, S. (1996). The Cultural Contradictions of Motherhood. New Haven and London: Yale University Press.

Herrera, F. (2011). The building of parental bonds: adoption and assisted reproduction in Chile. Revista de cercetare şi intervenţie socială, 32, 25-43. Retrieved from http://www.rcis.ro/images/documente/rcis32_02.pdf

Hill, P. (1994). Shifting the center: race, class and feminist theorizing about motherhood. In: Nanako Glenn, E. et al. (Eds.) Mothering. Ideology, Experience and Agency (pp. 45-65). New York and London: Routledge.

Hockey, J. \& James, A. (2003). Social Identities across the Life Course. New York: Palgrave Macmillan.

Instituto Nacional de Estadísticas. (2006). Fecundidad en Chile. Situación reciente. Santiago: INE.

Instituto Nacional de Estadísticas. (2007). Maternidad. Tendencias y variables influyentes. Santiago: INE.

Instituto Nacional de Estadísticas. (2008). Población y sociedad. Aspectos demográficos. Santiago: INE.

Instituto Nacional de Estadísticas. (2014). Compendio Estadístico 2014. Santiago: INE.

Kawash, S. (2011). New Directions in Motherhood Studies. Signs, 36 (4), 969-1003. doi: $10.1086 / 658637$

Kohli, M. (2007). The Institutionalization of the Life Course: Looking Back to Look Ahead. Research in Human Development, 4 (3-4), 253-271. doi: 10.1080/15427600701663122.

Larrañaga, O. (2007). Participación Laboral de las Mujeres en Chile: 1958-2003. Departamento de Economía, Universidad de Chile.

Lawler, S. (2000). Mothering the Self. Mothers, daughters and subjects. London and New York: Routledge.

Leccardi, C. \& Rampazi, M. (1993). Past and Future in Young Women's Experience of Time. Time \& Society, 2 (3), 353-379. doi: 10.1177/0961463X93002003004

Leccardi, C. (2005). Facing uncertainty. Temporality and biographies in the new century. Young. Nordic Journal of Youth Research, 13 (2), 123-146. doi: $10.1177 / 1103308805051317$

Lee, D. (2010). The early socioeconomic effects of teenage childbearing: A proponsity score matching approach. Demographic Research, 23, 697-736. doi: 10.4054/DemRes.2010.23.25

Lewis, S. (1991). Motherhood and Employment: The Impact of Social and Organizational Values. In: Phoenix, A. et al. (Eds.) Motherhood. Meanings, Practices and Ideologies (pp. 195-215). London, Newbury Park, New Delhi: Sage Publications.

Madhok, S., Phillips, A., \& Wilson, K. (2013). Gender, Agency and Coercion. Basingstoke and New York: Palgrave Macmillan. 
Maher, J. (2009). Accumulating care: Mothers beyond the conflicting temporalities of caring and work. Time \& Society, 18 (2/3), 231-245. doi: 10.1177/0961463X08099950.

Mahmood, S. (2005). Politics of Piety. The Islamic Revival and the Feminist Subject. Princeton and Oxford: Princeton University Press.

Mattingly, M. J. \& Bianchi, S. M. (2003). Gender Differences in the Quantity and Quality of Free Time: The U.S. Experience. Social Forces, 81 (3), 999-1030. doi: 10.1353/sof.2003.0036.

McAlister, J. F. (2008). Lives of the Mind/Body: Alarming Notes on the Tenure and Biological Clocks. Women's Studies in Communication, 31 (2), 218-225. doi: 10.1080/07491409.2008.10162536

McAlister, J. F. (2015). Policing Sexual and Reproductive Agency in U.S Public Culture. Women's Studies in Communication, 38 (2), 125-128. doi: 10.1080/07491409.2015.1034629

McNay, L. (2000). Gender and Agency. Reconfiguring the subject in feminist and social theory. Cambridge, Oxford and Malden: Polity Press and Blackwell Publishers.

Miller, T. (2005). Making Sense of Motherhood. A Narrative Approach. Cambridge, New York, Melbourne, Madrid, Cape Town, Singapore, Sao Paulo: Cambridge University Press.

Mills, M. (2000). Providing Space for Time: The Impact of Temporality on Life Course Research. Time \& Society, 9(1), 91-127. doi: 10.1177/0961463X00009001006

Ministerio de Salud, Servicio de Registro Civil e Identificación, \& Instituto Nacional de Estadísticas. (2014). Anuario de Estadísticas Vitales 2012. Santiago: INE.

Montecino, S. (1990). Símbolo mariano y constitución de la identidad femenina en Chile. Estudios Público, 39, 283-290. Retrieved from http://www.cepchile.cl/dms/archivo_1894_1220/rev39_montecino.pdf

Montilva, M. (2008). Postergación de la maternidad de mujeres profesionales jóvenes en dos metrópolis latinoamericanas. Utopía y Praxis Latinoamericana, 13 (41), 69-79. Retrieved from http://www.redalyc.org/articulo.oa?id=27904104

Murray, M. (2012). Childbirth in Santiago de Chile: Stratification, Intervention, and Child Centeredness. Medical Anthropology Quarterly, 26 (3), 319-337. doi: 10.1111/j.1548-1387.2012.01221.x

Nanako Glenn, E. (1994). Social Constructions of Mothering: A Thematic Overview. In: Nanako Glenn, E. et al. (Eds.) Mothering. Ideology, Experience and Agency (pp. 1-29). New York and London: Routledge.

O'Reilly, A. (2004). Introduction. In: O'Reilly, A. (Ed.) From Motherhood to Mothering. The Legacy of Adrienne Rich's Of Woman Born. New York: State University of New York Press.

O'Reilly, A. (2010a). Introduction. In: O'Reilly, A. ed. Twenty-first-Century Motherhood. Experience, Identity, Policy, Agency (pp. 1-20). New York: Columbia University Press.

O'Reilly, A. (2010b). Encyclopedia of Motherhood. Volumes I, II and III. Thousand Oaks, London, New Delhi and Singapore: SAGE Publications.

Obermeyer, C. M. (2000). Risk, Uncertainty, and Agency: Culture and Safe Motherhood in Morocco. Medical Anthropology, 19, 173-201. doi: 10.1080/01459740.2000.9966175.

Offer, S. \& Schneider, B. (2011). Revisiting the Gender Gap in Time-Use Patterns: Multitasking and Well-Being among Mother and Fathers in Dual-Earner Families. American Sociological Review, 76 (6), 809-833. doi: 10.1177/0003122411425170. 
Organisation for Economic Co-operation and Development. (2013). Income inequality. In: OECD Factbook 2013: Economic, Environmental and Social Statistics (pp66-67). Paris: OECD Publishing.

Pemjean, A., Toro, J.P., \& Barros, X. (2011). Salud mental en la intersección entre maternidad, familia y trabajo. In: Ansoleaga, E. Mujer, Trabajo, Maternidad, Salud. Tensiones no resueltas del siglo XX y propuestas para el Bicentenario ( $\mathrm{p}$. 151-207). Santiago: UDP.

Phoenix, A. (1991). Mothers under Twenty: Outsiders and Insider Views. In: Phoenix, A. et al. (Eds.) Motherhood. Meanings, Practices and Ideologies (pp. 86-102). London, Newbury Park, New Delhi: Sage Publications.

Phoenix, A. \& Woollett, A. (1991a). Introduction. In: Phoenix, A. et al. (Eds.) Motherhood. Meanings, Practices and Ideologies (pp. 1-12). London, Newbury Park, New Delhi: Sage Publications.

Phoenix, A. \& Woollett, A. (1991b). Motherhood: Social Construction, Politics and Psychology. In: Phoenix, A. et al. (Eds.) Motherhood. Meanings, Practices and Ideologies (pp. 13-27). London, Newbury Park, New Delhi: Sage Publications.

Pieper Mooney, J. E. (2009). The politics of motherhood. Maternity and women's rights in twentieth-century Chile. Pittsburgh: University of Pittsburgh Press.

Potter, A. E. \& Knaub, P. K. (1988). Single Motherhood by Choice: A Parenting Style. Lifestyles: Family and Economic Issues, 9 (3), 240-249. doi: 10.1007/BF00988935

Programa de las Naciones Unidas para el Desarrollo. (2010). Desarrollo Humano en Chile. Género: los desafíos de la igualdad. Santiago: PNUD.

Rich, A. (1995). Of Woman Born. Motherhood as Experience and Institution. New York and London: W. W Norton \& Company Ltd.

Rindfuss, R. R., Morgan, S. P., \& Swicegood, C. G. (1984). The Transition to Motherhood: The Intersection of Structural and Temporal Dimensions. American Sociological Review, 49 (3), 359-372. Retrieved from http://www.jstor.org/stable/2095280

Rose, J., Hewitt, B., \& Baxter, J. (2011). Women and part-time employment. Easing or squeezing time pressure? Journal of Sociology, 49 (1), 41-59. doi: $10.1177 / 1440783311419907$

Rothman, B. K. (2000). Recreating Motherhood. New Brunswick, New Jersey and London: Rutgers University Press.

Salvo, I. \& Gonzálvez, H. (2015). Monoparentalidades electivas en Chile: Emergencias, tensiones y perspectivas. Psicoperspectivas, 14 (2), 40-50. doi: 10.5027/PSICOPERSPECTIVAS-VOL14-ISSUE2-FULLTEXT-541

Sayer, L. C. (2005). Gender, Time and Inequality: Trends in Women's and Men's Paid Work, Unpaid Work and Free Time. Social Forces, 84 (1), 285-303. doi: 10.1353/sof.2005.0126

Schkolnik, S. (2004). La fecundidad en América Latina. In: La fecundidad en América Latina: ¿Transición o revolución? Serie Seminarios y Conferencias № 36 (pp. 33-47). Santiago: CELADE-CEPAL.

Schmidt-Hebbel, K. (2009). Chile's Growth and Development: Leadership, PolicyMaking Process, Policies and Results. Working Paper $\mathrm{N}^{\circ}$ 52, Commission on Growth and Development, The International Bank for Reconstruction and Development. Washington: The World Bank.

Schreier, M. (2014). Qualitative Content Analysis. In: Flick, U. (Ed.) The SAGE Handbook of Qualitative Data Analysis (pp. 170-184). London: SAGE Publications. 
Servicio Nacional de la Mujer \& Instituto Nacional de Estadísticas. (2004). Mujeres chilenas. Tendencias en la última década. Volume 2 and 3. Santiago: SERNAM-INE.

Servicio Nacional de la Mujer. (2012). Estudio sobre las principales preocupaciones y anhelos de las madres de hoy en Chile. Santiago: SERNAM.

Settersten, R. A. (2003). Age Structuring and the Rhythm of the Life Course. In: Mortimer, J. T. and Shanahan, M. J. (Eds.) Handbook of the Life Course (pp. 8198). New York: Kluwer Academic and Plenum Publishers.

Sevón, E. (2005). Timing Motherhood: Experiencing and Narrating the Choice to Become a Mother. Feminism and Psychology, 15 (4), 461-482. doi: 10.1177/0959-353505057619.

Simons, M. A. (1984). Motherhood, Feminism and Identity. Women's Studies International Forum, 7 (5), 349-359. doi: 10.1016/0277-5395(84)90034-7.

Smyth, L. (2012). The Demands of Motherhood. Agents, Roles and Recognition. Basingstoke and New York: Palgrave Macmillan.

The World Bank. (2011a). The Little Data Book on Gender. Washington: The World Bank.

Thornton, D. (2014). Transformations of the Ideal Mother: The Story of the Mommy Economicus and Her Amazing Brain. Women's Studies in Communication, 37 (3), 271-291. doi: 10.1080/07491409.2014.944734

Tietjens, D. (2002). Gender in the Mirror. Cultural Imagery \& Women's Agency. Oxford and New York: Oxford University Press.

Valdés, X. (2007). Notas sobre la metamorfosis de la familia en Chile. In: Futuros de las familias y desafíos para las políticas públicas (pp. 1-18). Santiago: CEPALUNFPA. 